\title{
Influence of seasonal variation on the hydro-biogeochemical characteristics of two upland lakes in the Southeastern Amazon, Brazil
}

\author{
PRAFULLA K. SAHOO ${ }^{1}$, JOSÉ T.F. GUIMARÃES ${ }^{1,2}$, PEDRO W.M. SOUZA-FILHO ${ }^{1,2}$, MARCIO S. DA \\ SILVA $^{1}$, RENATO O. SILVA JÚNIOR ${ }^{1}$, GUSTAVO PESSIM ${ }^{1}$, BERGSON C. DE MORAES ${ }^{1}$, PAULO F.P. \\ PESSOA $^{3}$, TARCÍSIO M. RODRIGUES ${ }^{4}$, MARLENE F. DA COSTA ${ }^{4}$ and ROBERTO DALL'AGNOL ${ }^{1,2}$ \\ ${ }^{1}$ Vale Institute of Technology, Rua Boaventura da Silva 955, Nazaré, 66055-090 Belém, PA, Brazil \\ ${ }^{2}$ Universidade Federal do Pará, Geosciences Institute, Programa de Pós-graduação em Geologia \\ e Geoquímica, Av. Augusto Correa 1, Guamá, 66075-110 Belém, PA, Brazil \\ ${ }^{3}$ Hidrovia - Hidrogeologia e Sustentabilidade, Rua Albita 131/301, Cruzeiro, 30310-160 Belo Horizonte, MG, Brazil \\ ${ }^{4}$ Gerência de Meio Ambiente - Minas de Carajás, Departamento de Ferrosos Norte, Estrada \\ Raymundo Mascarenhas, S/N, Mina de N4, 68516000 Parauapebas, PA, Brazil
}

Manuscript received on June 4, 2016; accepted for publication on August 26, 2016

\begin{abstract}
Limnological characteristics of the Violão and Amendoim lakes, in the Serra dos Carajás, Amazon, were studied interannually (2013-2014). Climate data indicate anomalous conditions during the 2013 rainy period with higher rainfall and lower temperature in the beginning (November). Lake levels were influenced after the first and second hour of each rainfall, which showed a strong synchronization between seasonal fluctuation of lake levels and local weather patterns. Based on the water quality, both lakes are classified as classes " 1 " and " 2 " in the CONAMA (Conselho Nacional do Meio Ambiente) scheme and as "excellent" to "good" in the WQI (Water Quality Index) categories. However, the limnology is distinctly different between the lakes and seasons. Higher trophic state and phytoplankton productivity were observed mainly during the rainy period in Violão Lake compared to Amendoim Lake. This may be due to deposition of leached nutrients in the former, mainly total phosphorus (TP), which was probably derived from mafic soils and guano. This is consistent with the significant positive correlation between Chlorophyll-a and TP at the end of the rainy period (March-April), whereas this was not observed in the beginning (November). This could possibly be a consequence of the more intense cloud cover, and unusual high rainfall that limits nutrient availability.
\end{abstract}

Key words: Upland lakes, water quality, phytoplankton biomass, Carajás Province.

\section{INTRODUCTION}

The upland lakes of Amazonia are recognized as important features in the landscape and provide an important biodiversity/shelter for plants and animals (Esteves 1998, Tundisi and Matsumara-

Correspondence to: Prafulla Kumar Sahoo

E-mail: prafulla.sahoo@itv.org / prafulla.iitkgp@gmail.com
Tundisi 2008, Lopes et al. 2011). These reservoirs are also useful as source of water for the surrounding ecosystem.

Based on the water quality characteristics, lakes can be susceptible to natural and anthropogenic eutrophication at low contaminant thresholds (Legesse et al. 2004). However, in a closed catchment-lake system with limited anthropogenic 
influence, natural processes such as local climate changes, which controls the hydrological characteristics of lakes, (water level, water temperature, precipitation and thermal stratification) (Niedda and Pirastru 2013), and the subsequent influence on physical, chemical and microbiological characteristics of the water body become important (Delpla et al. 2009, Whitehead et al. 2009). An increase in water temperature favors dissolution, solubilization, complexation, and evaporation processes, leading to increased dissolved substances and decreases in the dissolved gases (Delpla et al. 2009). Higher temperature encourages allow that water-borne organisms and accelerates biological processes, favoring a higher growth rate of phytoplankton and macrophytes (Wade et al. 2002, Iius and Keskitalo 2008). Annual and seasonal climatic variations can affect weathering rates, soil runoff, soil moisture, sedimentation rates and nutrient leaching, which may influence water quality and biological productivity (Lane et al. 2007, Hammond and Pryce 2007). Novo et al. (2006) demonstrated the occurrence of seasonal changes of phytoplankton biomass in Amazon floodplain lakes, where the chlorophyll-a concentration was increased and the lakes were enriched in dissolved nutrients when the water level decreased. Further, Whitehead et al. (2009) and Cox and Whitehead (2009) reported that changes in temperature and rainfall influenced the mobility and concentration of nutrients such as nitrogen and phosphorous, which are the most important parameters for phytoplankton (Reynolds et al. 2002, Molisani et al. 2010, Wilhelm et al. 2011). However, assessing phytoplankton growth is not as straightforward as it may occur as a result of the complex interplay between nutrient availability, light conditions, temperature, water residence time and flow conditions (Jeppesen et al. 2005). Moreover, increasing phytoplankton growth can lead to serious ecological problems, such as eutrophication, and can also be a potential source of contamination of lake water because of the toxins produced by cyanobacteria which impair the ability to maintain aquatic life (Affonso et al. 2011). Therefore, understanding the factors involved in water quality monitoring is vital to managing water resources. In Brazil, the water quality information for many hydrographical basins is still limited or in some cases does not exist (ANA 2005). Furthermore, most investigations were undertaken on floodplain lakes and reservoirs (Molisani et al. 2010, Affonso et al. 2011), while studies on tropical upland lakes are scanty. This is particularly true for the closed-basin lake systems of the Amazonia region where knowledge of biota and driving forces acting on them is limited (Lopes et al. 2011).

The present study was carried out on two upland lakes (Violão and Amendoim) in the Carajás Mineral Province in the southeastern Amazon region. These lakes are closed catchment-lake systems developed over an extensive ferruginous duricrust on a plateau region. The comprehensive physical, chemical and microbiological characterization of the water of these two lakes was undertaken interannually (2013-2014) along with hydroclimatic parameters to explore the water quality and phytoplankton dynamics and their relationship with local weather patterns. In addition, it can be helpful to better understand the limnological processes working in Amazonian upland lakes and to be able extend this to similar lacustrine environments.

\section{STUDY AREA}

The studied lakes are located in the National Forest of Carajás, a law-protected area located in the southern sector of the Serra dos Carajás, SE Amazon region, Brazil (Figure 1a). These lakes are developed at an elevation of $600-800 \mathrm{~m}$ above mean sea level (amsl) on a ferruginous duricrust, which is vegetated by montane savanna bordered by Amazon rainforest (Figure 1a). The whole catchment area measures $3.89 \mathrm{~km}^{2}$ (Figure $1 \mathrm{~b}$ ). The longer drainages flow from south to northward 
and the morphology of the terrain is asymmetric, with the lakes showing a steeper northern flank and a flatter southern one. There are three closed catchment-lake systems in the studied area (Figure 1b): i) Violão is the largest one and has a surface area of $1.83 \mathrm{~km}^{2}$ with altitude ranging from 765 to $730 \mathrm{~m}$ amsl, ii) Amendoim has a surface area of $1.23 \mathrm{~km}^{2}$ with altitude ranging from 720 to 710 $\mathrm{m}$ amsl, and iii) the intermediate catchment is a closed watershed with surface area of $0.86 \mathrm{~km}^{2}$ and altitude ranging from 710 to $700 \mathrm{~m}$ amsl (Figure 1c). A clear topographic scaling down was observed from Violão to Amendoim catchment-lake system, where the difference was around $20 \mathrm{~m}$ of height (Figure 1c). Additionally, there was no superficial connection between the lakes. Caves only occur in the catchment of Violão Lake, whose volume ranges from 3 to $2553 \mathrm{~m}^{3}$, with concentrated and dispersed occurrence of guano (Carste 2010), which may be a source of phosphorous to Violão Lake. Additionally, altered mafic rocks, which are also potential sources of phosphorous, were found only in the northwestern portion of Violão Lake (Sahoo et al. 2015). In contrast, both caves and mafic rock outcrops were not observed around the catchment of Amendoim Lake.

The lakes are formed by structural and dissolution processes on the extensive lateritic crust (Golder 2010). Violão Lake has a northeasternsouthwestern (NE-SW) elongated guitar shaped form (Figure 1a), maximum water depth of around $10 \mathrm{~m}$ and a flat and muddy bottom (Sahoo et al. 2015). Amendoim Lake has north-south elongated form (Figure 1a), maximum water depth of around
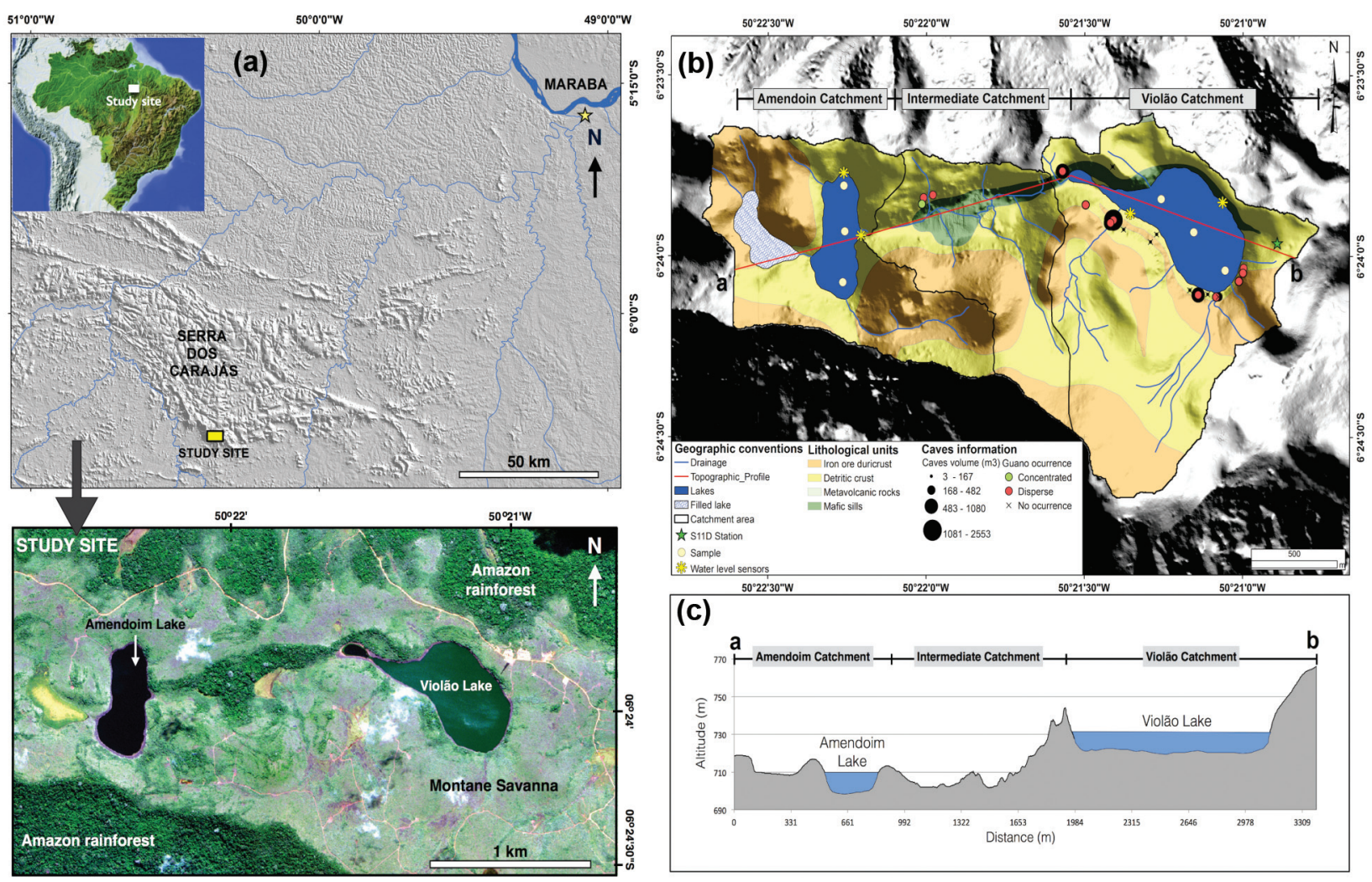

Figure 1 - a) Location of the study site and nearby cities. Worldview-2 image in color composite 5R3G1B, showing Amendoim and Violão lakes; b) Lithological and morphological characteristic of the catchment of Amendoim and Violão lakes, with location of caves as well as the position of the water level sensors, water sample points and S11D meteorological station; c) Topographic profile showing the difference of water level between Violão and Amendoim lakes. 
$8 \mathrm{~m}$ and an irregular, muddy and partially vegetated bottom (macrophytes) with some lateritic outcrops. In this area, ferruginous duricrusts are extensively developed over banded iron formations (BIFs), and are mainly represented by duricrusts and detritic crusts (Resende and Barbosa 1972, Morais et al. 2011, Silva et al. 2009). Sills of intensely altered mafic rocks are locally observed in the northwestern portion of Violão Lake (Figure 1b). Open forest and small patches of high-and-low forest occur over detritic crust and mafic sills, while montane savanna develops over iron-ore duricrust and detritic crust and occupy most of the area (Golder 2010, Guimarães et al. 2014).

The regional climate is tropical monsoon (Alvares et al. 2014), with a mean annual temperature of around $26^{\circ} \mathrm{C}$. According to Moraes et al. (2005), the total annual precipitation ranges from 1800 to $2300 \mathrm{~mm}$, with a total mean of around $1550 \mathrm{~mm}$ during the rainy season (November May) and of $350 \mathrm{~mm}$ during the dry season (June - October).

\section{MATERIALS AND METHODS}

Hourly rainfall and water level data for 2013 and 2014 were obtained, respectively, from the S11D meteorological station (Vantage Pro2, Davis Instruments) near Violão Lake and Water Level Sensors (UNIK 500 Pressure Sensing Platform GE), which installed in the margins of the studied lakes (Figure 1b). For the identification of climate season of the study area, monthly rainfall data of 2013-2014 were treated according to the completelinkage cluster analysis using Euclidean distance.

Pearson's $r$ correlation test was applied to evaluate the time lag in which rainfall starts to influence lake level. We have measured the correlations between (i) the total rainfall within one hour and (ii) the lake level (L) in the following hours (from Lt0 [current hour] to Lt+10 [plus 10 hours]). The highest correlation indicates the hour in which the lake is most influenced by rainfall.
A multispectral high spatial resolution image of satellite Worldview-2 was acquired on $19^{\text {th }}$ May 2013 (Figure 1a), which allowed to observe the differences in water color between the Violão and Amendoim lakes. These lakes were sampled in the dry and rainy seasons of 2013-2014. Three sampling points were chosen from each lake following longitudinal profiles (Figure 1b) based on the bathymetric map and drainage patterns. In these points, physicochemical parameters such as temperature, $\mathrm{pH}$, dissolved oxygen (DO), conductivity, turbidity, and total dissolved solid (TDS) were determined in-situ by a Water Quality Monitoring System (Horiba W-20XD). Also 15-L water samples were collected using a Van Dorn Bottle Sampler and stored following ABNT (1987) and SMEWW (2005) (Supplementary Material, Table SI). The inorganic, organic and bacteriological parameters were analyzed in the water samples by using the SGS Geosol analytical facility following EPA (2004), SMEWW (2005) and CETESB $(2005,2014)$ guidelines.

Numerous classification methods have been proposed to measure the trophic state index (TSI) of lakes employing single nutrient ( $\mathrm{P}$ or $\mathrm{N}$ ) or physical (secchi disk) measurement to more complex multiparameters (Carlson 1977, Lambou et al. 1983). The Carlson index is based on three limnological variables which are highly correlated with each other (Carlson 1977) and it has been widely used for assessing the trophic state of trophical/subtrophic lakes. Recently, a modified Carlson Index proposed by Lamparelli (2004) is being considered as more accurate for the classification of the trophic status of trophical/subtrophic reservoirs. It has been widely applied in evaluating various water reservoirs in South America (Molisani et al. 2010). In the present study, TSI of the lakes was obtained by using the modified Carlson index (Table I), following to the equations:

$T S I(C h l)=10(6-(0.92-0.34(\ln C h l / \ln 2))(11)$ 


$$
\begin{gathered}
T S I(T P)=10(6-(1.77-0.42(\ln T P)-\ln 2)) \\
T S I(S D)=10(6-((\ln T S D) / \ln 2))
\end{gathered}
$$

where: $\mathrm{Chl}=$ Chlorophyll $-a(\mu \mathrm{g} / \mathrm{l})$, and $\mathrm{TP}=$ Total $\mathrm{P}(\mu \mathrm{g} / \mathrm{l}), \mathrm{SD}=$ Secchi disk $(\mathrm{m})$.

Water quality of both lakes was evaluated through the Environmental National Council (CONAMA) Resolution No. 357/2005 (Brasil 2005). This guideline describes the limit of each parameter separately. To synthesize multi parameters into a single number, Water Quality Index (WQI) is developed. The Brazilian WQI is an adaptation from the National Sanitation Foundation (NSF) index established by Brown et al. (1970) (equation 4), using the weighted scores of a set of nine specific variables: temperature, $\mathrm{pH}$, dissolved oxygen (DO), biochemical oxygen demand (BOD), thermotolerant coliforms, dissolved inorganic nitrogen, total phosphorus, total solids and turbidity. Each parameter is weighted by a value w between 0 and 1 and the sum of all weights is 1 (CETESB 2004-2006).

$$
W Q I=\prod_{i=1}^{n} q_{i}^{w_{i}}
$$

where, wi $=$ relative weight of the $i^{\text {th }}$ parameter, a number between 0 and 1 assigned according to their importance to the overall conformation of quality, where $\sum_{i=1}^{n} w i=1$. qi $=$ relative quality of the $\mathrm{i}^{\text {th }}$ variable, which ranged from 0 to 100 and was obtained from the respective standard quality curve as a function of concentration (Brown et al. 1970), $\mathrm{i}=$ number of variable. The result is expressed by a number between 0 and 100, divided in 5 quality ranges: (100-79) — excellent quality, (79-51) good quality, (51-36) - fair quality, (36-19) - poor quality, [19-0] - bad quality (CETESB 20042006).

\section{RESULTS}

\section{HYDROCLIMATE PARAMETERS}

The patterns of wind velocity and direction (Figure 2a) in the study site for 2013 show slight variation of wind velocity ( $\sim 3$ to $4 \mathrm{~m} / \mathrm{s}$ ) with prevailing direction from the NE and ENE. However, the wind velocity in 2014 significantly varied from $2.5 \mathrm{~m} / \mathrm{s}$ in March to $\sim 5 \mathrm{~m} / \mathrm{s}$ in August (Figure 2a), with wind direction mainly from the NE and ENE. The mean minimum and maximum air temperature for 2013 were $20.7{ }^{\circ} \mathrm{C}$ and $31.9{ }^{\circ} \mathrm{C}$, respectively, with the highest values at the end of March to September, while the lowest temperatures occurred in November-December (Figure 2b). In general, the temperatures for 2014 were lower than 2013, with mean minimum and maximum of $19{ }^{\circ} \mathrm{C}$ and $30.4^{\circ} \mathrm{C}$, respectively, and the highest temperatures in August-September.

Based on the monthly rainfall for 2013-2014 (Figure 2c), the drier period of 2013 extended from June to September, ranging from 28 to $88 \mathrm{~mm}$. The

TABLE I

Water bodies classiffication according to the trophic state index (TSI) of Carlson (1977) modified by Lamparelli (2004). TP: total phosphorus, Chl-a: Chlorophyll-a.

\begin{tabular}{ccccc}
\hline Classification & Range & $\begin{array}{c}\text { Secchi } \\
(\mathbf{m})\end{array}$ & $\begin{array}{c}\text { TP } \\
(\boldsymbol{\mu g} / \mathbf{l})\end{array}$ & $\begin{array}{c}\text { Chl-a } \\
(\boldsymbol{\mu g} / \mathbf{l})\end{array}$ \\
\hline Ultraoligotrophic & $\mathrm{TSI} \leq 47$ & $\mathrm{~S} \geq 2.4$ & $\mathrm{P} \leq 8$ & $\mathrm{CL} \leq 1.17$ \\
Oligotrophic & $47<\mathrm{TSI} \leq 52$ & $2.4>\mathrm{S} \geq 1.7$ & $8<\mathrm{P} \leq 19$ & $1.17<\mathrm{CL} \leq 3.24$ \\
Mesotrophic & $52<\mathrm{TSI} \leq 59$ & $1.7>\mathrm{S} \geq 1.1$ & $19<\mathrm{P} \leq 52$ & $3.24<\mathrm{CL} \leq 11.03$ \\
Eutrophic & $59<\mathrm{TSI} \leq 63$ & $1.1>\mathrm{S} \geq 0.8$ & $52<\mathrm{P} \leq 120$ & $11.03<\mathrm{CL} \leq 30.5$ \\
Supereutrophic & $63<\mathrm{TSI} \leq 67$ & $0.8>\mathrm{S} \geq 0.6$ & $120<\mathrm{P} \leq 233$ & $30.5<\mathrm{CL} \leq 69.05$ \\
Hypereutrophic & $\mathrm{TSI}>67$ & $0.6>\mathrm{S}$ & $233<\mathrm{P}$ & $69.05<\mathrm{CL}$ \\
\hline
\end{tabular}


wetter conditions of the rainy period (October to May) were recorded from the end of April to May and during November-December with $279 \mathrm{~mm}$ and 329-248 mm, respectively (Figure 2c, right and lower corner), while from January to March it ranged from 147 to $236 \mathrm{~mm}$. The total annual precipitation was around $1930 \mathrm{~mm}$. In general, 2014 was wetter than 2013 with values varying from 8 to $90 \mathrm{~mm}$ during the drier period (June to September), and from 163 to $339 \mathrm{~mm}$ during the rainy period (October to May). Based on multivariate data analysis for 2013-2014, the dry season is extended from June to September (Fig 3a, group 1), the rainy season from October to May (Figure 3a, group 2 and 3).
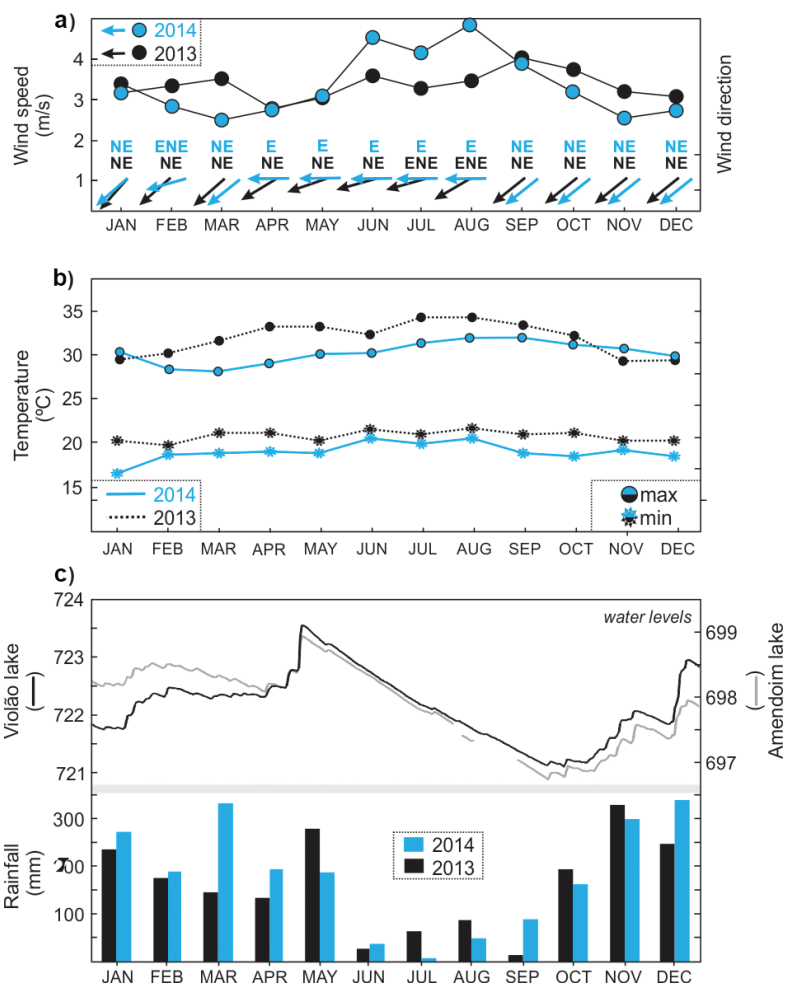

Figure 2 - a) Wind intensity and direction at the S11D station during 2013 ; b) maximum and minimum air temperature $\left({ }^{\circ} \mathrm{C}\right)$ at the S11D station (left corner) and rainfall (right corner, dashed line) data at the S11D station during 2013 (lower corner), and 30yr-median rainfall of wettest months (FebMar-Apr; square symbols) and driest months (Sep-Oct-Nov, rhombuses symbols) at the Marabá Station (upper corner); c) Water level changes in Violão (left corner) and Amendoim (right corner) lakes during 2013.
Considering the water level, both Violão and Amendoim lakes (Figure 2c) have shown similar behavior with rainfall. In Violão Lake, water level oscillated from 722.4 to 722.9 m between January and April, rising to $723.3 \mathrm{~m}$ in May and then dropping to its lowest level of $720.9 \mathrm{~m}$ in October,
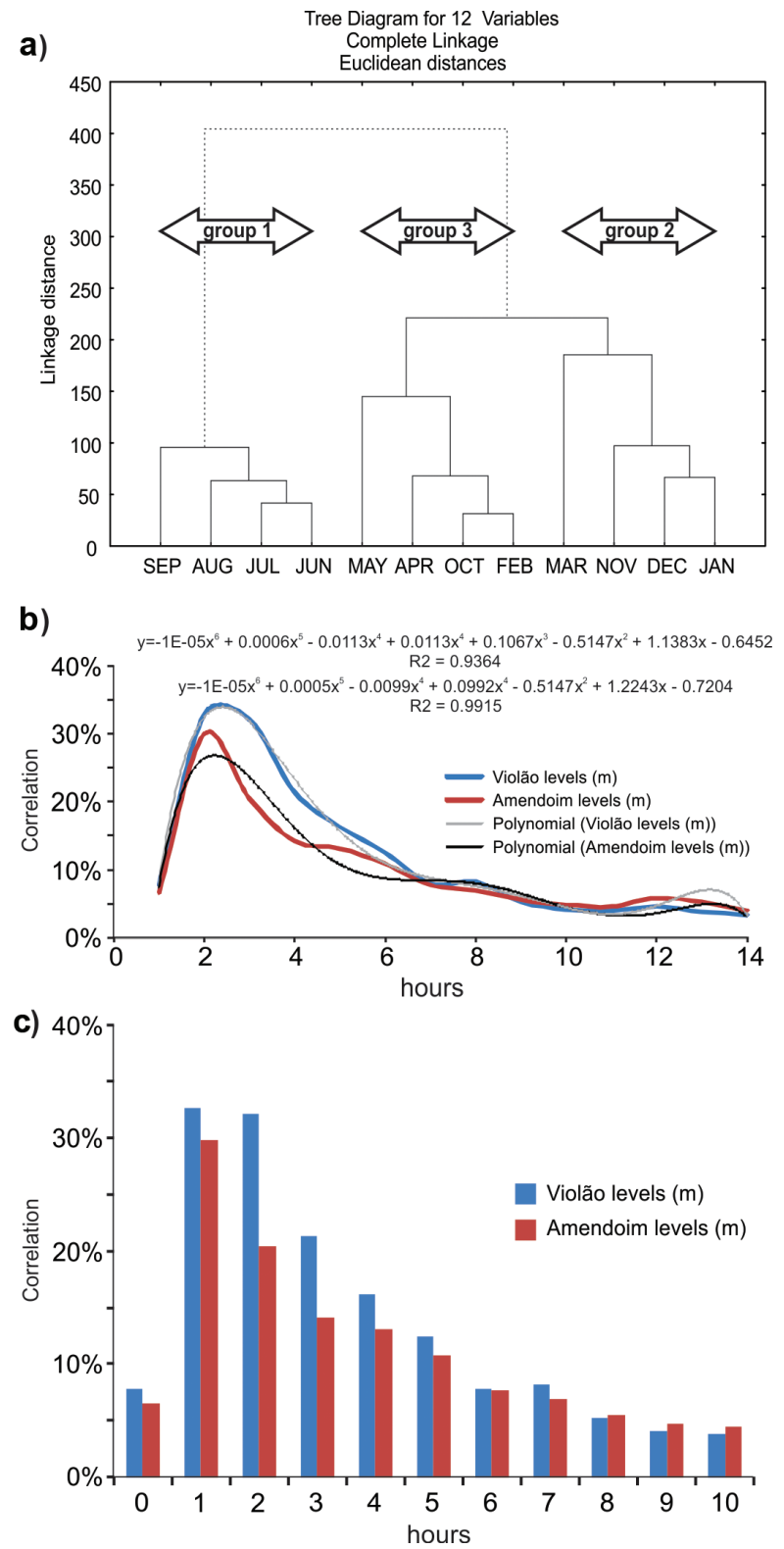

Figure 3 - a) Cluster analysis of the rainfall data of 2013-2014: the dry season extend from June to September (group 1), the rainy season from October to May (group 2 and 3); Pearson's $\mathrm{r}$ correlation test between the total rainfall and the lake level in the following hours: b) Line plot with polynomial regression; c) Bar plot. 
and rising again to $722.2 \mathrm{~m}$ in December (Figure 2c, left and lower corner). In Amendoim Lake, the water level rose from 697.5 to $699 \mathrm{~m}$ from January to May, fell to $696.9 \mathrm{~m}$ in October, and then rose to $698.5 \mathrm{~m}$ in December (Figure 2c, right and lower corner).

Based on distribution patterns for hourly rainfall and water level data of Violão and Amendoim lakes, Shapiro-Wilk Normality Test (Shapiro and Wilk 1965) indicated values of $<0.05$ (p-value $<$ $\left.2.2 \mathrm{e}^{-16}\right)$, which is not an acceptable normal value, using 95\% confidence (Figure 3b). The Pearson's $r$ correlation test was used to evaluate the time lag it takes for rainfall to influence lake levels (Figure 3b). The impact of rainfall on lake levels has a correlation of approximately $32-33 \%$ and 20 $30 \%$ for Violão and Amendoim lakes, respectively, for the first and second hour after the start of the rainfall (Figure 3c). This indicates that the first and second hour of rainfall have the highest impact on lake level fluctuations.

\section{WATER QUALITY CHARACTERISTICS}

The descriptive statistics for the selected physicochemical and biological parameters recorded during the rainy (March and April) and dry (July and September) periods of 2013 and 2014 for Violão and Amendoim lakes are presented in Table II; while the detailed results of various physical, chemical and microbiological parameters are presented in Table SI. The selective water parameters for both lakes are presented in Box-whisker plots (Figure 4). At Violão Lake (Table II), the water temperature varied from 25.3 to $27.6{ }^{\circ} \mathrm{C}$ and 27.2 to $28.9{ }^{\circ} \mathrm{C}$ in the wet and dry periods, respectively. At Amendoim Lake, the temperature varied from 25.5 to $27.5^{\circ} \mathrm{C}$ in the wet period and 26.5 to $28.1{ }^{\circ} \mathrm{C}$ in the dry period. Lake conditions show a seasonal variation of temperature with relatively weak thermocline trend in both periods (Table SI).

At Violão Lake, $\mathrm{pH}$ ranged from acidic to slightly alkaline (4.39 - 7.28), while at Amendoim
Lake, the water remained acidic (4.02 - 6.71) (Figure 4, Table II). The more acidic waters were generally observed at greater depths. Neither lake showed a significant variation in $\mathrm{pH}$ based on changes in weather or season. Dissolved oxygen (DO) varied from 6.24 to $10.2 \mathrm{mg} / \mathrm{L}$ in Violão Lake, with the higher DO values occurring in the rainy period (mainly in March and April) and no significant variation of DO with depth observed (Table SI). In Amendoim Lake, DO values were less variable and averaged lower $(7.05$ to $7.6 \mathrm{mg} / \mathrm{L})$ than in Violão Lake, and were almost constant with depth (Table SI). BOD is $\leq 2 \mathrm{mg} / \mathrm{L}$ in both lakes (Table SI), indicating a very low level of organic pollution (Revelle and Revelle 1988).

Total Organic Carbon (TOC) and turbidity were higher in Violão Lake, mainly at the beginning of the rainy period (November), and varied from 3.9 to $5.1 \mathrm{mg} / \mathrm{L}$ and 2.7 to $4.5 \mathrm{NTU}$, respectively. Lower values were measured in March (Table II). At Amendoim Lake, both were low (below detection limits, BDL) to $3 \mathrm{mg} / \mathrm{L}$ and 0.48 to 2.23 NTU, respectively) and nearly constant in both periods (Table II).

The concentrations of TP varied widely. Higher values were observed in the Violão Lake which ranged from 10 to $50 \mu \mathrm{g} / \mathrm{L}$ TP and 10 to $150 \mu \mathrm{g} / \mathrm{L}$ $\mathrm{TP}$ in dry and rainy period, respectively (Figure 4 , Table II). In contrast, very low concentrations $(<20 \mu \mathrm{g} / \mathrm{L})$ of TP were recorded in both periods in Amendoim Lake. Nitrate-N $\left(\mathrm{NO}_{3}-\mathrm{N}\right)$ values in Violão Lake fluctuated between 0.2 and $0.59 \mathrm{mg} / \mathrm{L}$, while in Amendoim Lake, it varied from 0.03 to $0.41 \mathrm{mg} / \mathrm{L}$, with the maximum concentration observed in November (Figure 4, Table II).

Chl- $a$ concentration varied significantly between lakes (Figure 4, Table II). In Violão Lake, the higher concentration were observed during the rainy period (up to $38 \mu \mathrm{g} / \mathrm{L}$ ), except in November where the concentrations dropped (BDL to $4.49 \mu \mathrm{g} / \mathrm{L}$ ). Furthermore, with respect to depth, the maximum concentration was recorded 

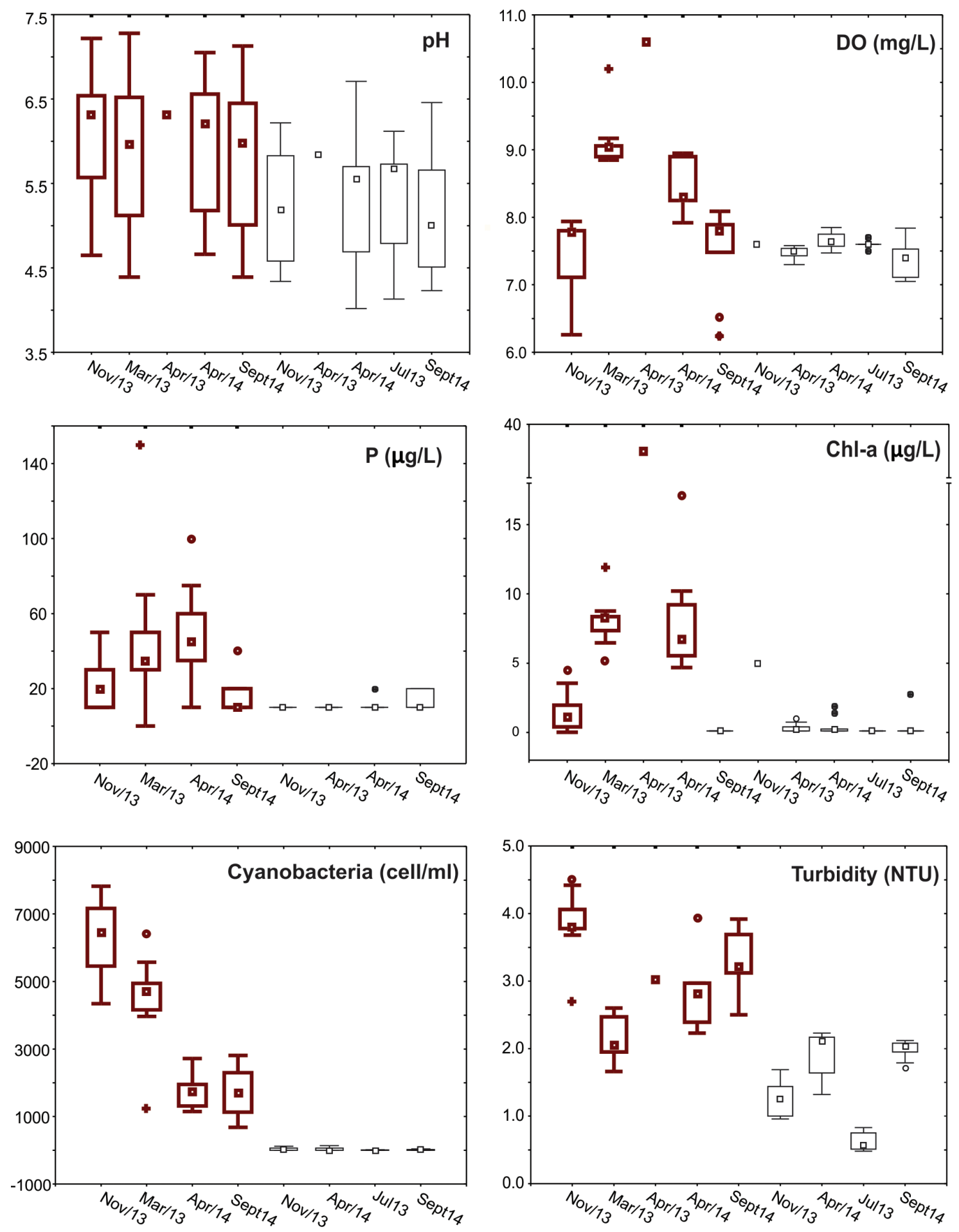

- Median

$\square 25 \%-75 \%$

Violão Lake

Amendoim Lake

I Non-Outlier Range

- Outliers

+ Extremes

Figure 4 - Box and whisker plot for selected physicochemical and biological parameters in different period of the Violão and Amendoim lakes. 
in surface waters (Table SI). On the other hand, very low content of Chl- $a$ (mostly BDL to 2.7 $\mu \mathrm{g} / \mathrm{L}$ ) was recorded in Amendoim Lake (Table II). Cyanobacteria counts varied between lakes, but did not seem to be seasonally dependent (Figure 4). Unusually high counts of Myxophyceae species varying from 678 to 7821 cell $/ \mathrm{mL}$ were recorded in Violão Lake, but at Amendoim Lake, these species were scarce $(<150$ cell $/ \mathrm{mL})$.

The Secchi depth (lake water transparency) for the two lakes quite different. In Violão Lake the Secchi depth varied from $1 \mathrm{~m}$ to $1.9 \mathrm{~m}$, while

TABLE II

The physico-chemical and biological parameters in wet (March, April and November) and dry (July and September) period of Violão and Amendoim lakes.

\begin{tabular}{|c|c|c|c|c|c|c|c|c|c|c|c|c|}
\hline & & $\begin{array}{l}\text { Temp } \\
\left({ }^{\circ} \mathrm{C}\right)\end{array}$ & $\begin{array}{c}\mathrm{NO}_{3} \\
(\mathrm{mg} / \mathrm{L})\end{array}$ & $\begin{array}{c}\mathrm{TP} \\
(\mu \mathrm{g} / \mathrm{L})\end{array}$ & $\begin{array}{c}\mathrm{DO} \\
(\mathrm{mg} / \mathrm{L})\end{array}$ & $\mathrm{pH}$ & $\begin{array}{l}\text { Turbidity } \\
\text { (NTU) }\end{array}$ & $\begin{array}{c}\text { Ecoil } \\
\text { (UFC/mL) }\end{array}$ & $\begin{array}{c}\text { TOC } \\
(\mathrm{mg} / \mathrm{L})\end{array}$ & $\begin{array}{c}\text { Cyanobacteria } \\
(\text { cell } / \mathrm{mL})\end{array}$ & $\begin{array}{l}\text { Chl-a } \\
(\mu \mathrm{g} / \mathrm{L})\end{array}$ & $\begin{array}{l}\text { Secchi } \\
(\mathrm{m})\end{array}$ \\
\hline \multicolumn{13}{|c|}{ Violão Lake } \\
\hline \multirow{3}{*}{ Mar/13 } & Max & 27.0 & 0.03 & 150 & 10.20 & 7.28 & 2.60 & BDL & BDL & 6414 & 12 & \\
\hline & Min & 26.5 & 0.03 & BDL & 8.85 & 4.39 & 1.66 & BDL & BDL & 1225 & 5.18 & \\
\hline & Avg & 26.7 & 0.03 & 48.3 & 9.13 & 5.85 & 2.13 & $\mathrm{BDL}$ & $\mathrm{BDL}$ & 4448 & 8.06 & 1.4 \\
\hline \multirow{3}{*}{ Nov/13 } & Max & 25.9 & 0.59 & 50 & 7.94 & 7.22 & 4.5 & 24.00 & 5.10 & 7821 & 4.49 & \\
\hline & Min & 25.3 & 0.20 & BDL & 6.26 & 4.65 & 2.7 & BDL & 3.90 & 4345 & $\mathrm{BDL}$ & \\
\hline & Avg & 25.6 & 0.37 & 22.2 & 7.44 & 6.05 & 3.84 & 5.11 & 4.36 & 6175 & 1.50 & 1.8 \\
\hline \multirow[t]{2}{*}{ Apr/13 } & Avg & 26.5 & - & & 10.60 & 5.51 & 3.02 & - & 3 & - & 38.0 & 1.0 \\
\hline & Max & 27.6 & 0.2 & 100 & 8.95 & 7.05 & 4.93 & 50 & 3.00 & 2720 & 17 & \\
\hline \multirow[t]{3}{*}{ Apr/14 } & Min & 26.1 & 0.2 & BDL & 7.92 & 4.66 & 2.2 & BDL & 2.10 & 1152 & 4.69 & \\
\hline & Avg & 26.9 & 0.2 & 47.2 & 8.6 & 5.95 & 3.01 & 22.2 & 2.44 & 1782 & 8.08 & 1.5 \\
\hline & Max & 28.9 & 0.32 & 40 & 8.09 & 7.13 & 3.92 & 16 & 3.5 & 2808 & $\mathrm{BDL}$ & \\
\hline \multirow[t]{2}{*}{ Sept/14 } & Min & 27.2 & 0.2 & BDL & 6.24 & 4.39 & 2.5 & BDL & 2.3 & 678 & $\mathrm{BDL}$ & \\
\hline & Avg & 27.8 & 0.21 & 15.5 & 7.50 & 5.78 & 3.29 & 5.3 & 2.63 & 1645 & $\mathrm{BDL}$ & 1.9 \\
\hline \multicolumn{13}{|c|}{ Amendoim Lake } \\
\hline \multirow[t]{2}{*}{ Apr/13 } & Avg & 26.3 & 0.05 & - & - & 7.5 & & - & $\mathrm{BDL}$ & - & 5 & 4.5 \\
\hline & $\operatorname{Max}$ & 26.3 & 0.41 & BDL & 7.58 & 6.22 & 1.69 & 86.00 & 2.60 & 120 & 0.97 & \\
\hline \multirow[t]{3}{*}{ Nov/13 } & Min & 25.5 & 0.30 & $\mathrm{BDL}$ & 7.30 & 4.34 & 0.96 & 12.00 & 2.10 & 0 & $\mathrm{BDL}$ & \\
\hline & Avg & 26.0 & 0.39 & BDL & 7.48 & 5.21 & 1.29 & 37.78 & 2.32 & 43 & 0.30 & 4.3 \\
\hline & $\operatorname{Max}$ & 27.5 & 2.6 & BDL & 7.85 & 6.7 & 2.23 & 45 & 3 & 64 & 1.9 & \\
\hline \multirow[t]{3}{*}{ Apr/14 } & Min & 26.8 & 0.56 & BDL & 7.47 & 4.02 & 1.32 & 5 & 2.1 & 0 & BDL & \\
\hline & Avg & 27.2 & 1.6 & BDL & 7.65 & 5.4 & 1.88 & 19 & 2.5 & 24 & - & 3.5 \\
\hline & $\operatorname{Max}$ & 27.2 & 0.04 & 20 & 7.70 & 6.12 & 0.83 & BDL & BDL & 19 & BDL & \\
\hline \multirow[t]{3}{*}{$\mathrm{Jul} / 13$} & Min & 26.5 & 0.03 & BDL & 7.40 & 4.13 & 0.48 & BDL & BDL & 0 & BDL & \\
\hline & Avg & 26.8 & 0.03 & BDL & 7.59 & 5.35 & 0.63 & BDL & BDL & 5 & $\mathrm{BDL}$ & 4.0 \\
\hline & Max & 28.1 & 0.35 & 20 & 7.84 & 6.46 & 2.12 & 9 & 2.9 & 41.3 & 2.7 & \\
\hline \multirow[t]{3}{*}{ Sept/14 } & Min & 26.8 & BDL & BLD & 7.05 & 4.23 & 1.72 & 7 & 2.2 & 0 & BDL & \\
\hline & Avg & 27.3 & - & - & 7.3 & 5.2 & 1.98 & 8.3 & 2.7 & 13.4 & - & 3.8 \\
\hline & $\mathrm{BDL}$ & & $<0.03$ & $<10$ & & & & $<1$ & $<2$ & & $<0.1$ & \\
\hline
\end{tabular}

Max: maximum; Min: Minimum; Avg: Average; Temp: temperature, TP: total phosphorous, Ecoli: Escherichia coli, Chl-a: Chlorophyll-a; BDL: below detection limit; '-' data not available. 
in Amendoim Lake values varied from 3.5 to 4.5 m (Table II). Reflectance values extracted from Worldview-2 image in 5R3G1B color composition showed the same trend when compared with chl- $a$ content, turbidity and transparence. Figure 1a shows the reflectance of Amendoim and Violão water obtained in the Worldview-2 image, acquired in May 2013, and associated with physicochemical and biological parameters measured in the field in March and April 2013.

\section{TROPIC STATE INDEX (TSI)}

The TSI of both lakes during different periods are given in Figure 5a. They indicate that Violão Lake can be classified as supereutrophic in March and April, mesotrophic in November (rainy season), and Oligotrophic in September (dry season), while Amendoim Lake can be classified as ultraoligotrophic (July and November) and slightly oligotrophic (April and September).

\section{WATER QUALITY INDEX (WQI)}

The WQI values (Figure 5b) range from 65.6 to 86.1 and 63 to 79.8 in Violão and Amendoim lakes, respectively. This indicates good quality in both lakes and Violão Lake could attain a rating of excellent quality.

\section{DISCUSSION}

\section{HYDROCLIMATIC CHANGES}

About $66 \%$ of the moisture that contributes to rainfall over the eastern and western Amazon is provided by the incoming air from the Atlantic Ocean (Costa and Foley 1999), while the rest of the moisture is supplied through evapotranspiration from the forests (Davidson et al. 2012). The importance of the evapotranspiration of forests may impact the rainfall gradient over the Amazon region from the predominantly rainy west to the wet/dry climate and long dry season of the eastern regions (Davidson et al. 2012). According to Davidson et al. (2012), this weather gradient is coincident with gradual changes in land-use, with more conversion to agriculture in the drier eastern region, indicating a possible relationship between biophysical and socio-economic processes. Similarly, Souza Filho et al. (2015) indicate that $50 \%$ of the primary forest cover in this region (in the legally protected area) has been converted to pasturelands (bare soil, pasture, agriculture). However, the impacts of these land use changes may not yet exceed the magnitude of natural variability of hydrologic cycles, but they do signal that transition to a disturbance-dominated regime must be considered as a climate driver (Davidson et al. 2012).
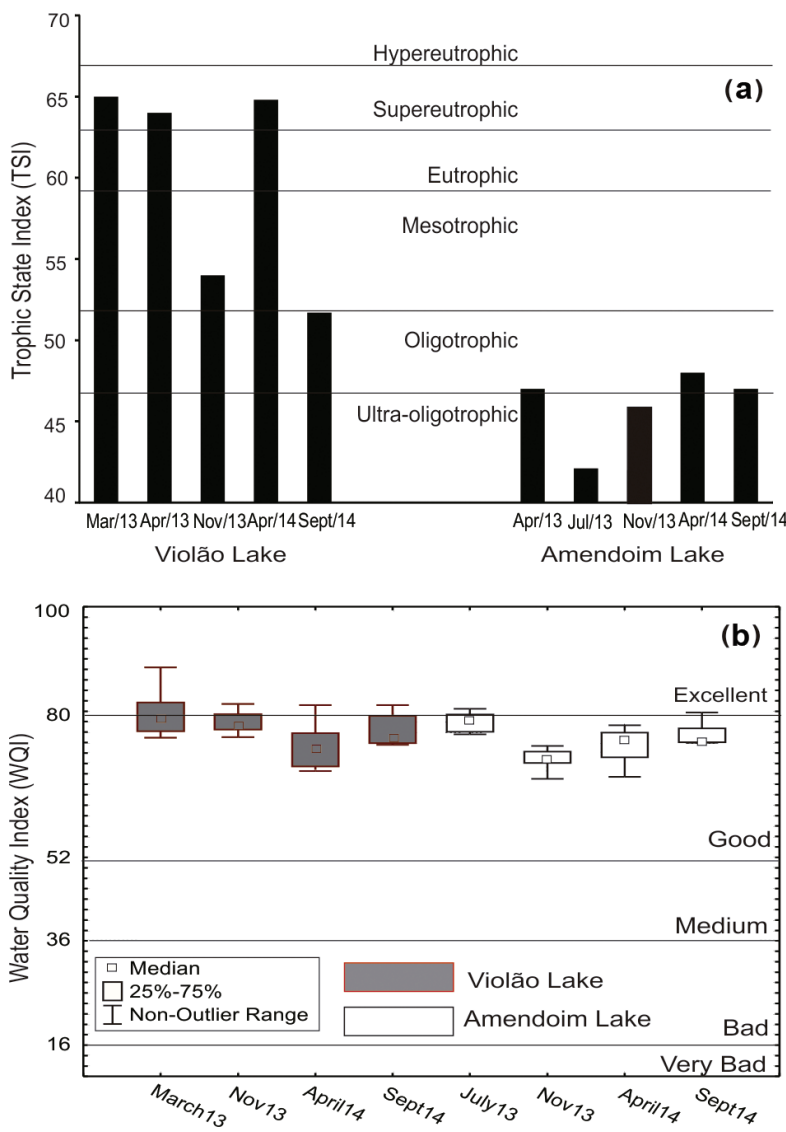

Figure 5 - a) Trophic State Index (TSI) of the Violão and Amendoim lakes during wet and dry period of 2013-2014; b) Water quality index (WQI) of the of the Violão and Amendoim lakes in different climatic period in 2013-2014. 
Considering the effects of climate seasonality on lacustrine environments, it is widely demonstrated that the rainfall regime in short time scales has a direct influence on lake levels of the Amazon region (Bush et al. 2002, Bush and Silman 2004, Bush and Metcalfe 2012). However, information related to how long lake levels respond to daily or monthly rainfall variations is almost unknown. This does not entail a simple correlation of rainfall volume with lake levels; this type of correlation is non-linear, as was observed in this study using data on hourly rainfall and resulting water levels at the Violão and Amendoim lakes $(r \sim-0.01)$. Moreover, Spearman's rank correlation indicates that lake levels are influenced after the first and second hour of each rainfall fall (Figure 3b, c), which indicates that part of the substrate of the basin is subjected to intense runoff (Hidrovia 2013). During the dry period, evaporation and bottom infiltration substantially exceeded rainfall, decreasing the water levels of the lakes (Amplo 2013).

As demonstrated by Guimarães et al. (2014), the predominance of montane savanna in the studied area is related to edaphic conditions, where the type of substrate (mostly ferruginous duricrust) and low water retention allow the widespread development of plant species adapted to nutrient and hydric stress and hinder the colonization of tree species. Otherwise, forest formation only occurs in isolated areas with rock types that are much more easily weathered, and develop thicker soil horizon and higher nutrient and water availability/retention, which allow the development of tree species. Therefore, rainfall, catchment basin characteristics and lake levels are directly related with each other and may be used as driving forces to explain seasonal changes in the water quality of the Violão and Amendoim lakes.

\section{EVALUATION OF WATER QUALITY}

The determination of water quality involved by comparing the results with various quality stan- dards. In Brazil, Resolution No. 357/2005, Brazilian National Environmental Council (Brasil 2005) is widely used as the standard for monitoring water quality and for allowable water quality targets (Moretto et al. 2012); this resolution provides classification ranges from Class I (highest quality) to class IV (low quality) to compare water quality. Class I is suitable for more prime use, such as human consumption, watering livestock, and protection of aquatic life. The same is true for Class II, except for human consumption, the water needs treatment using conventional processes (Brasil 2005). According to CONAMA resolution $\mathrm{n}^{\circ}$ $357 / 05$, levels of DO, $\mathrm{NO}_{3}^{-}, \mathrm{NO}_{2}^{-}, \mathrm{NH}_{4}, \mathrm{SO}_{4}^{2-}, \mathrm{Cl}^{-}$, TP, chlorophyll-a found in Amendoim Lake correspond to Class I (Table III). In Violão Lake, the levels of chlorophyll-a and TP correspond to Class II, while the levels of $\mathrm{DO}, \mathrm{NO}_{3}^{-}, \mathrm{NO}_{2}^{-}, \mathrm{NH}_{4}, \mathrm{SO}_{4}^{2-}$, and $\mathrm{Cl}^{-}$correspond to Class I. This was further shown by the Water Quality Index (WQI), which indicates that the waters of Violão and Amendoim lakes can be classified as good with Violão straddling the field of excellence (Figure 5b).

\section{WATER QUALITY RELATIVE TO CATCHMENT CHARACTERISTICS}

The most important water quality variables are $\mathrm{pH}, \mathrm{DO}, \mathrm{TOC}$, turbidity, fecal coliform, chl-a, cyanobacteria, secchi depth and TP, which show high variability in the studied lakes. Trophic State, which was calculated based on TP, Chl-a and Secchi depth, indicates that Violão Lake was supereutrophic in the end of the rainy season and mesoeutrophic in its beginning (Figure 5a) with high phytoplankton biomass (Chl- $a$ and cyanobacteria), and high $\mathrm{pH}, \mathrm{DO}$, turbidity, and TP (Figure 4). On the other hand, during the same period, Amendoim Lake was ultra-oligotrophic to oligotrophic, with low phytoplankton biomass, and low pH, DO, turbidity and P (Figure 4). This variability in trophic state may be due to different physiographic characteristics of each catchment 
basin, which control nutrients levels as well as phytoplankton biomass. Increase in the tropic state related to high TP content suggests that the role of nutrients, particularly $\mathrm{P}$, could be the key parameter controlling trophic state in the lakes. The major sources of $\mathrm{P}$ to lakes are rock weathering and anthropogenic sources such as agriculture, sewage and urban effluents. However, for Amendoim and Violão lakes anthropogenic activity and related sources can be discarded. At Violão lake, P-enrichment comes from soils derived from mafic rocks and guano form the caves and margins of the catchment through leaching or erosional transport. In contrary, absence of P-enrichment around Amendoim lake can be explained by the different geological and physiographic setting (Figure 1b). These results show that catchment characteristics can be an important factor influencing the trophic state of lakes. A recent study by Catherine et al. (2010) has also demonstrated that the trophic status of water bodies can be predicted based on catchment attributes.

Eutrophication of a lake system is a gradual progression from one life stage to another based on nutrient input or productivity (Sharma et al. 2010).
In general, ultra-oligotrophic lakes host very little or no vegetation and have clear water, while mesoeutrophic/hypereutrophic lakes exhibit higher vegetation and unclear water. In the latter, the continuous input of organic matter may increase the probability of anoxia in hypolimnion. Considering the higher TSI for Violão Lake, it is speculated that after a period of several years this lake may host significant quantities of phytoplankton, including algal bloom, under natural eutrophication conditions, as has been observed in other Amazon lakes (Affonso et al. 2011, Alves et al. 2012). Besides nutrients, water $\mathrm{pH}$ is significantly different between lakes (Figure 4), which can be linked with phytoplankton growth (Hansen 2002, Wang et al. 2011). Hansen (2002) studied the effect of $\mathrm{pH}$ on phytoplankton biomass and found that the uptake of inorganic carbon by phytoplankton during photosynthesis has the potential to increase the $\mathrm{pH}$ in the surrounding water. Findlay (2003) also demonstrated that increased $\mathrm{pH}$ was related to the influence of phytoplankton assemblages. Thus, the increase of $\mathrm{pH}$ in Violão Lake may be due to accentuated phytoplankton growth in that water body. On the other hand, lower $\mathrm{pH}$ at the

TABLE III

Classification of freshwater bodies according to the CONAMA Resolution No. 357 (CONAMA 2005).

\begin{tabular}{|c|c|c|c|c|c|c|}
\hline \multirow[b]{2}{*}{ Variables } & \multirow[b]{2}{*}{ Unit } & \multirow[b]{2}{*}{ Violão Lake } & \multirow[b]{2}{*}{ Amendoim Lake } & \multicolumn{3}{|c|}{ Resolução CONAMA 357/2005 } \\
\hline & & & & Class I & Class II & Class III \\
\hline$\overline{\mathrm{DO}}$ & $\mathrm{mg} / \mathrm{L}$ & $6.26-10.2$ & $7.05-7.85$ & $>6$ & $>5$ & $>4$ \\
\hline $\mathrm{pH}$ & - & $4.39-7.28$ & $4.02-6.71$ & 6 to 9 & 6 to 9 & 6 to 9 \\
\hline TP & $\mu \mathrm{g} / \mathrm{L}$ & $10-150$ & $10-20$ & $<200$ & $<300$ & $<500$ \\
\hline $\mathrm{NO}_{3}^{-}$ & $\mathrm{mg} / \mathrm{L}$ & $0.03-9.39$ & $0.03-2.63$ & $<10$ & $<10$ & $<10$ \\
\hline $\mathrm{NO}_{2}^{-}$ & $\mathrm{mg} / \mathrm{L}$ & $<0.05$ & $<0.05$ & 1 & 1 & 1 \\
\hline $\mathrm{NH}_{4}$ & $\mathrm{mg} / \mathrm{L}$ & $0.03-0.1$ & $0.03-0.1$ & $<3.7$ & $<3.7$ & $<13.3$ \\
\hline $\mathrm{SO}_{4}^{2-}$ & $\mathrm{mg} / \mathrm{L}$ & $<0.05$ & $<0.05$ & 250 & 250 & 250 \\
\hline $\mathrm{Cl}^{-}$ & $\mathrm{mg} / \mathrm{L}$ & $<1-1.4$ & $<1$ & 250 & 250 & 250 \\
\hline Chl-a & $\mu \mathrm{g} / \mathrm{L}$ & $0.1-38$ & $0.1-5$ & $<10$ & $<30$ & $<60$ \\
\hline Cyanobacteria & cell $/ \mathrm{ml}$ & $678-7821$ & $0-120$ & 20,000 & 100000 & 100000 \\
\hline
\end{tabular}

Class I: These waters that can be designed to supply for human consumption after simplified treatment; Class II designed to supply for human consumption after treatment conventional; Class III: water that can be designed to supply for consumption human after conventional or advanced treatment. 
bottoms of both lakes can possibly be explained by degradation of sedimentary organic matter.

\section{LIMNOLOGICAL CHARACTERISTICS RELATIVE TO SEASONAL WEATHER VARIABILITY}

Rainfall and temperature patterns vary seasonally and control the water levels in the lakes and can influence water quality. Higher Chl- $a$ content was found near the end of the rainy season (MarchApril), which is characterized by a higher rainfall index, higher water level, lower temperature and higher TP. However, if only the weather behavior is considered during the rainy season, there is a trend of increasing temperature during March-April, which possibly causes an increase in light intensity. This is one of the important factors that facilitate photosynthesis, thereby favoring the growth of plankton biomass with the reduction of carbon dioxide from water and liberation of oxygen. Significantly higher values of DO and Chl- $a$ during wet period as compared to drier period is a clear indication of the increase of photosynthesis. A lower Chl- $a$ content was noticed in the beginning of the rainy season (November) compared to the end (March-April). This may be due to the relatively high rainfall and higher cloud clover, which reduces the light intensity/solar radiation, limiting primary productivity (Le Cren and Lowe-McConnel 1980). High rainfall can increase sedimentation rates, producing more allochtonous material, and limit the residence time of nutrients (Straškraba 1999, Novo et al. 2013). This idea is supported by the significant positive correlation between Chl- $a$ and TP $(\mathrm{r} \sim 0.62)$ at the end of the wet period (MarchApril), in contrast with the weak correlation $(r \sim$ 0.16 ) in the beginning of wet period (November) (Figure 6). Zhu et al. (2005) also reported that water quality is controlled to weather seasonality, which has an important impact in the mobility of $\mathrm{P}$. Nitrate is also an important limiting factor for Chl-a, however, the weak correlation $(r<0.1)$ between these factors (Figure 6) suggests that $\mathrm{NO}_{3}$ played no significant role. Increases in TOC and turbidity in lake water may also cause unfavorable conditions for the growth of phytoplankton (Shuhaimi-Othman et al. 2007); because both promote absorption and backscattering of light, which decreases the penetration of ultraviolet light and decrease Chl- $a$ content (Morris et al. 1995). Chl- $a$ and cyanobacteria are more abundant in Violão Lake than Amendoim Lake, but cyanobacteria showed variable behavior in relation to Chl- $a$. The highest abundance of cyanobacteria was observed in November, just after the driest period was registered. Algal blooms might occur during the drier period, but not subsequently in November, since Chl- $a$, the strongest indicator of photosynthetic activity, was very low and weekly correlated with TP (Figure 6). Thus, TOC may be related with decomposition of macrophytes during periods of low-water levels and dead of cyanobacteria cells. Although, during this time of the year TP concentrations were low, the concentration of $\mathrm{NO}_{3}$ was high. However, the absence of correlation between cyanobacteria and $\mathrm{NO}_{3}$ (Figure 6) indicates that multiple factors controlled their abundance. Other processes that could influence stratification of waters and nutrient distribution in the studied lake are the wind velocity and direction (Figure 2a). However, the distribution of the hydrochemical parameters of Violão Lake and Beaufort wind force scale generally suggest no significant influence of currents based on wind velocities as registered. Thus, regional and local weather changes, catchment basin characteristics and lake levels are inter-related and may be considered as the main driving forces to explain differences in hydro-biogeochemical characteristics of the Amendoim and Violão upland closed catchment-lake system of the southeastern Amazon.

\section{CONCLUSIONS}

The hydroclimatic characteristics of Violão and Amendoim Lakes for 2013-2014 indicate that 

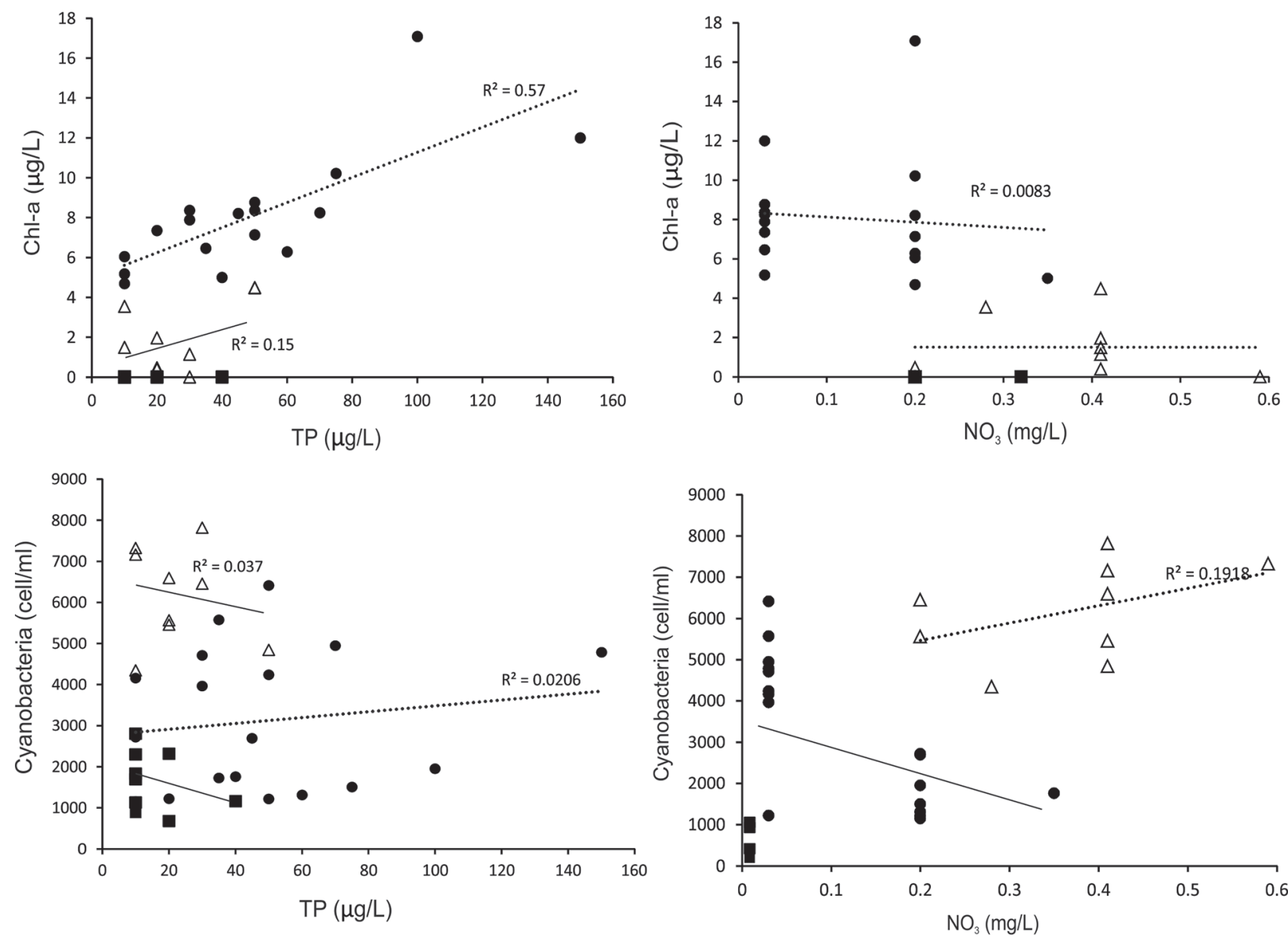

- March-April

$\triangle$ November

- July-September

Figure 6 - Binary plot of the selected water quality parameters of the Violão Lake: a) Chl- $a$ vs total phosphorous-TP; b) Cyanobacteria vs TP; c) Cyanobacteria vs $\mathrm{NO}_{3}$; d) and Cyanobacteria vs total organic carbon-TOC.

the water levels were strongly influenced by local rainfall patterns. Based on the CONAMA Resolution no. 375/2005, and WQI, both lakes are classified as class "I" to "II" and "excellent" to "good" categories, respectively. With respect seasonal weather periods, the water characteristics varied significantly - higher trophic state and higher phytoplankton biomass were observed in Violão Lake than Amendoim Lake. The higher TP content of Violão Lake indicates that catchment characteristic is one of the major factors controlling water quality. Higher trophic state as well as higher Chl- $a$ content in Violão Lake in the end of the rainy season (March-April) is likely due to a relative increase of temperature, which facilitates nutrient availability and enhances photosynthesis. This is reinforced by the positive relationship between Chl- $a$ and TP in Violão Lake from March to April, butnot in its beginning at November. This is possibly due to higher rainfall that leads to increased rates of sedimentation and limits nutrient availability. A general conclusion is that phytoplankton biomass is dependent on seasonal dynamics of the nutrient profile and catchment characteristics of the basin.

\section{ACKNOWLEDGMENTS}

We would like to acknowledge the financial support and field assistance provided by Vale 
Institute of Technology and Conselho Nacional de Desenvolvimento Científico e Tecnológico (CNPq) (479182/2012-4, 442088/2014-0). The authors thank the members of DIPF, GELIF, DIST, LISF, LAMSF of Vale S.A. for the field support and scientific discussions. This project was carried out in the National Forest of Carajás under permission of IBAMA (SISBIO 35594-2).

\section{REFERENCES}

ABNT - ASSOCIAÇAO BRASILEIRA DE NORMAS TÉCNICAS. 1987. NBR 9898:1987 - Preservação e técnicas de amostragem de efluentes líquidos e corpos receptores.

AFFONSO AG, BARBOSA C AND NOVO E. 2011. Water quality changes in floodplain lakes due to the Amazon River flood pulse: Lago Grande de Curuaí (Pará). Braz J Biol 71: 601-610.

ALVARES CA, STAPE JL, SENTELHAS PC, GONÇALVES JLM, AND SPAROVEK G. 2014. Köppen's climate classification map for Brazil. Meteorol Z 22: 711-728.

ALVES ICC, EL-ROBRINI M, SANTOS MLS, MONTEIRO SM, BARBOSA LPF AND GUIMARÃES JTF. 2012. Qualidade das águas superficiais e avaliação do estado trófico do Rio Arari (Ilha de Marajó, norte do Brasil). Acta Amaz 42: 115-124.

AMPLO. 2013. Funcionalidade ecológica das lagoas do Violão e do Amendoim, S11D. Relatório Interno DIPF/ GELIF/VALE, p. 553.

ANA - AGÊNCIA NACIONAL DE ÁGUA. 2005. Panorama da qualidade das água superficiais no Brasil. ANA: Brasília - DF, $68 \mathrm{p}$.

BRASIL. 2005. Ministério do Desenvolvimento Urbano e Meio Ambiente. Conselho Nacional do Meio Ambiente CONAMA. 2005. Resolução no 357, de 17 de março de 2005. Dispõe sobre a classificação dos corpos de água e diretrizes ambientais para o seu enquadramento, bem como estabelece as condições e padrões de lançamento de efluentes, e dá outras providências Diário Oficial da República Federativa do Brasil, Brasília, DF, 18 mar. 2005.

BROWN RM, MCCLELLAND NI, DEININGER RA AND TOZER RG. 1970. A water quality index: Do we dare? Water Sewage Works 117: 339-343.

BUSH MB AND METCALFE SE. 2012. Latin America and the Caribbean. In: Metcalfe SE and Nash DJ (Ed), Quaternary Environmental Change in the Tropics, $1^{\text {st }}$ ed., J Wiley \& Sons, Ltd. p. 263-311.

BUSH MB, MILLER MC, DE OLIVEIRA PE AND COLINVAUX PA. 2002. Orbital forcing signal in sediments of two Amazonian lakes. J Paleolimnol 27: 341352.
BUSH MB AND SILMAN MR. 2004. Observations on Late Pleistocene cooling and precipitation in the lowland Neotropics. J Quat Sci 19: 677-684.

CARLSON RE. 1977. Atrophic state index for lakes. Limnol Oceanogr 22: 361-369.

CARSTE. 2010. Espeleologia do Projeto S11D Serra Sul, Região de Carajás, PA. Belo Horizonte. Vale, Espeleologia do Projeto S11D. Internal Report, $231 \mathrm{p}$.

CATHERINE A, MOUILLOT D, ESCOFFIER N, BERNARD C AND TROUSSELLIER M. 2010. Cost effective prediction of the eutrophication status of lakes and reservoirs. Freshwater Biol 55: 2425-2435.

CETESB - COMPANHIA DE TECNOLOGIA DE SANEAMENTO AMBIENTAL. 2004-2006. Companhia de Tecnologia de Saneamento Ambiental. Companhia de Tecnologia de Saneamento Ambiental. Relatório 57 de Qualidade das Águas Interiores do Estado de São Paulo, São Paulo.

CETESB - COMPANHIA DE TECNOLOGIA DE SANEAMENTO AMBIENTAL. 2005. Método de Ensaio L5.303 Dez/2005 Fitoplâncton de água doce métodos qualitativo e quantitativo. Companhia de Tecnologia de Saneamento Ambiental, Secretária de Meio Ambiente, Estado de São Paulo.

CETESB - COMPANHIA DE TECNOLOGIA DE SANEAMENTO AMBIENTAL. 2014. Método de Ensaio L5.306 Fev/2014 Determinaçao de pigmentos fotossintetizantes Clorofila abc e Feofitina a. Companhia de Tecnologia de Saneamento Ambiental, Secretária de Meio Ambiente, Estado de São Paulo.

COSTA MH AND FOLEY JA. 1999. Trends in the hydrologic cycle of the Amazon basin. J Geophys Res 104: 1418914198.

COX BA AND WHITEHEAD PG. 2009. Potential impacts of climate change on dissolved oxygen in the river Thames. Hydrol Res 40: 138-152.

DAVIDSON EA ET AL. 2012. The Amazon basin in transition. Nature 481: 321-328.

DELPLA I, JUNG AV, CLEMENT BM AND THOMAS CO. 2009. Impacts of climate change on surface water quality in relation to drinking water production. Environ Int 35: $1225-1233$.

EPA. 2004. Method 9060A - Total organic carbon. 5P. Revision 1. United States Environmental Protection Agency.

ESTEVES FA. 1998. Fundamentos de Limnologia. $2^{\text {nd }}$ ed., Rio de Janeiro: Interciência, p. 602.

FINDLAY DL. 2003. Response of phytoplankton communities to acidification and recovery in Killarney park and the experimental lakes area, Ontario. AMBIO 3293: 190-195.

GOLDER. 2010. Anexo IV - Geologia. Estudo de Impacto Ambiental, EIA Projeto Ferro Carajás S11D.

GUIMARÃES JTF ET AL. 2014. Source and distribution of pollen and spores in surface sediments of a plateau lake in southeastern Amazonia. Quat Int 26: 181-196. 
HAMMOND D AND PRYCE AR. 2007. Climate change impacts and water temperature. Environment Agency Science Report, SC060017/SR, Bristol, UK, p. 102.

HANSEN PJ. 2002. Effect of high $\mathrm{pH}$ on the growth and survival of marine phytoplankton: implications for species succession. Aquat Microb Ecol 2825: 279-288.

HIDROVIA 2013. Balanço hídrico das Lagoas do Violão e do Amendoim. Relatório Interno DIPF/GELIF/VALE.

IIUS E AND KESKITALO J. 2008. The response of phytoplankton to increased temperature in the Lovisa archipelago, Gulf of Finland. Boreal Environ Res 13: 503516.

JEPPESEN E ET AL. 2005. Lake responses to reduced nutrient loading - an analysis of contemporary long-term data from 35 case studies. Freshwater Biol 50: 1747-1771.

LAMBOU VW, TAYLOR WD, HERN SC AND WILLIAMS LR. 1983. Comparison of trophic state measurements. Water Res 17: 1619-1983.

LAMPARELLI MC. 2004. Degrees of trophy in water bodies of São Paulo: Evaluation of monitoring methods. Doctoral Thesis, Institute of Biosciences, University of São Paulo, São Paulo, 235 p.

LANE SN, REID SC, TAYEFI V, YU D AND HARDY RJ. 2007. Interactions between sediment delivery, channel change, climate change and flood risk in a temperate upland environment. Earth Surf Process Landf 32: 429446.

LE CREN ED AND LOWE-MCCONNELL RH. 1980. The Functioning of Freshwater Ecosystems, Cambridge University Press, Cambridge, p. 588.

LEGESSE D, VALLET-COULOMB C AND GASSE F. 2004. Analysis of the hydrological response of a tropical terminal lake, Lake Abiyata (Main Ethiopian Rift Valley) to changes in climate and human activities. Hydrol Process 18: 487-504.

LOPES PM, CALIMAN A, CARNEIRO LS, BINI LM, ESTEVES FA, FARJALLA V AND BOZELLI RL. 2011. Concordance among assemblages of upland Amazonian lakes and stucturing role of spatial and environmental factors. Ecol Eng 11: 1171-1176.

MOLISANI MM, BARROSO HS, BECKER H, MOREIRA MOP, HIJO CAG, MONTE TM AND VASCONCELLOS GH. 2010. Trophic state, phytoplankton assemblages and limnological diagnosis of the Castanhão Reservoir, CE, Brazil. Acta Limnol Bras 22: 1-12.

MORAES BC, COSTA JMN, COSTA ACLM AND COSTA MH. 2005. Variação espacial e temporal da precipitação no estado do Pará. Acta Amaz 35: 207-214.

MORAIS MC, MARTINS PPM AND PARADELLA WR. 2011. Mapping iron-mineralized laterite environments based on textural attributes from MAPSAR image simulation - SAR R99B (SIVAM/SIPAM) in the Amazon Region. Rev Bras Geofís 29: 99-111.
MORETTO DL, PANTA RE, COSTA AB AND LOBO EA. 2012. Calibration of water quality index (WQI) based on Resolution no 357/2005 of the environmental national council (CONAMA). Acta Limnol Bras 24: 29-42.

MORRIS DP, ZAGARESE H, WILLIAMSON CE, BALSEIRO EG, HARGREAVES BR, MODENUTTI B, MOELLER R AND QUEIMALINOS C. 1995. The attenuation of solar UV radiation in lakes and the role of dissolved organic carbon. Limnol Oceanogr 40: 13811391.

NIEDDA M AND PIRASTRU M. 2013. Hydrological processes of a closed catchment-lake system in a semi-arid Mediterranean environment. Hydrol Process 27: 36173626.

NOVO EML, BARBOSA CCF, FREITAS RM, SHIMABUKURO YE, MELACK JM AND FILHO WP. 2006. Seasonal changes in chlorophyll distrubution in Amazon floodplain lake derived from MODIS images. Limnol 7: 153-161.

RESENDE NP AND BARBOSA ALM. 1972. Relatório de Pesquisa de Minério de Ferro, Distrito Ferrífero da Serra dos Carajás, Estado do Pará. AMZA. Final Report, v.1, $248 \mathrm{p}$.

REVELLE P AND REVELLE C. 1988. The Environment: Issues and Choices for Society, Jones and Bartlett Publishers, Boston.

REYNOLDS CS, HUSZAR VL, NASELLI-FLORES L AND MELO S. 2002. Towards a functional classification of the freshwater phytoplankton. J Plankton Res 24: 417-428.

SAHOO PK, SOUZA-FILHO PWM, GUIMARÃES JTF, SILVA MS, COSTA FR, MANES CLO, OTI D, SILVA JÚNIOR RO AND DALL'AGNOL R. 2015. A multi-proxy geochemical study of surface sediments in a plateau lake of Carajás in the southeastern Amazon region: implication for provenance and post depositional processes. Appl Geochem 52: 130-146.

SHAPIRO SS AND WILK MB. 1965. An analysis of variance test for normality (complete samples). Biometrika 52 (34): 591-611.

SHARMA MP, KUMAR A AND RAJVANSHI S. 2010. Assessment of Trophic State of Lakes: A Case of Mansi Ganga Lake in India. Hydro Nepal 6: 64-72.

SHUHAIMI-OTHMAN M, LIM EC AND MUSHRIFAH I. 2007. Water quality changes in Chini Lake, Pahang, West Malaysia. Environ Monit Assess 131: 279-292.

SILVA AQ, PARADELLA WR, FREITAS CC AND OLIVEIRA CG. 2009. Relationship Between PALSAR Backscatter and Surface-Roughness Parameters From Iron Laterites in Carajás, Amazon Region. IEEE Trans Geosci Remote Sens 47: 4027-4031.

SMEWW. 2005. 1060 - Collection and preservation of samples. Standard Methods for the Examination of Water and Wastewater. 
SOUZA-FILHO PWM, NASCIMENTO JRWR, VERSIANI DE MENDONÇA BR, SILVA JR. RO, GUIMARÃES JTF, DALL'AGNOL R AND SIQUEIRA JO. 2015. Changes in the land cover and land use of the Itacaiunas River watershed, arc of deforestation, Carajás, southeastern Amazon. ISPRS - International Archives of the Photogrammetry, Remote Sensing and Spatial Information Sciences, v. XL-7/W3, p. 1491-1496.

STRAŠKRABA M. 1999. Retention time as a key variable of reservoir limnology. In: Tundisi JG and Straškraba M (Eds), Theoretical reservoir ecology and its applications. São Carlos: International Institute of Ecology, Brazilian Academy of Sciences and Backhuys Publishers, p. 385410.

TUNDISI JG AND MATSUMARA-TUNDISI T. 2008. Limnologia. Oficina de Textos, São Paulo, p. 63.

WADE AJ, WHITEHEAD PG, HORNBERGER GM AND SNOOK D. 2002. On modeling the flow controls on macrophytes and epiphyte dynamics in a lowland permeable catchment: the River Kennet, southern England. Sci Total Environ 282-283: 395-417.

WANG X, HAO C, ZHANG F, FENG C AND YANG Y. 2011. Inhibition of the growth of two blue-green algae species (Microsystis aruginosa and Anabaena spiroides) by acidification treatments using carbon dioxide. Bioresour Technol 102: 5742-5748.

WHITEHEAD PG, WILBY RL, BATTARBEE RW, KERNAN MAND WADE A.J. 2009. A review of the potential impacts of climate change on surface water quality Hydrological Sciences. Hydrolog Sci J 54: 101-123.

WILHELM SW, FARNSLEYA SE, LECLEIR GR, LAYTON AC, SATCHWELL MF, DEBRUYN JM, BOYER GL, ZHU G AND PAERL HW. 2011. The relationships between nutrients, cyanobacterial toxins and the microbial community in Taihu (Lake Tai), China. Harmful Algae 10:207-215.

ZHU Z, ARP PA, MAZUMDER A, MENG F, BOURQUE CPA AND FOSTER NW. 2005. Modeling stream water nutrient concentrations and loadings in response to weather condition and forest harvesting. Ecol Model 185: 231-243.

\section{SUPPLEMENTARY MATERIAL}

TABLE SI - The physicochemical and biological parameters of Violão and Amendoim lake. TP: total phosphorous; Ecoli: Escherichia coli; Chl-a: Chlorophyll-a; BDL: below detection limit. 